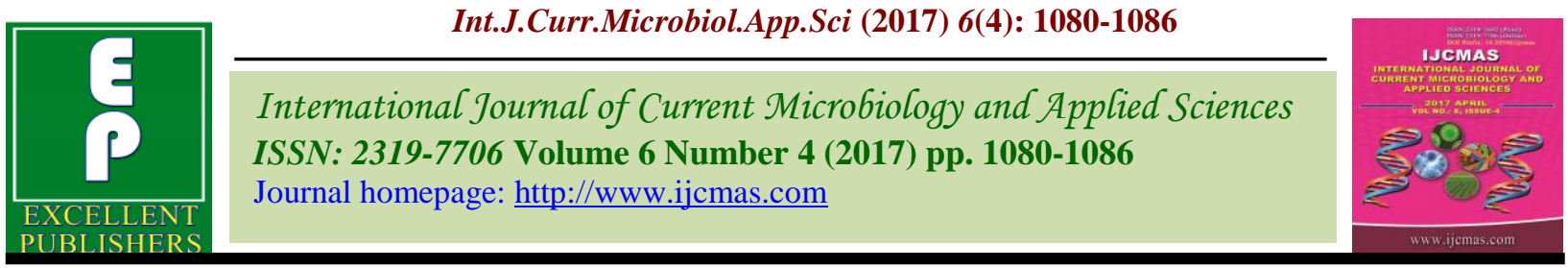

Original Research Article

https://doi.org/10.20546/ijcmas.2017.604.134

\title{
Evaluation of Different Germplasm and Insecticides against Tomato Leaf Curl Virus Affecting Tomato
}

\author{
Dechan Choskit, Ranbir Singh*, Sonali Bhagat, Kausar Fatima, \\ Manika Sharma and Sachin Gupta
}

\author{
Division of Plant Pathology, FOA, main campus Chatha of SKUAST-Jammu- 180009, India \\ *Corresponding author
}

\begin{tabular}{|c|c|}
\hline & A B S T R A C T \\
\hline $\begin{array}{l}\text { K e y w o r d s } \\
\text { Tomato leaf curl } \\
\text { disease, germplasm, } \\
\text { insecticides, } \\
\text { management. }\end{array}$ & $\begin{array}{l}\text { Tomato leaf curl disease caused by tomato leaf curl virus (ToLCV) is a major limiting } \\
\text { factor in tomato cultivation in Jammu region of Jammu and Kashmir. Screening of } \\
\text { different germplasm collected from different sources against the disease showed that out of } \\
\text { fifteen germplasm, Mahaveer and Avinash- } 2 \text { were found resistant, Samrudhi F1 and } \\
\text { Namdhari } 82535 \text { were found moderately resistant while eleven germplasm viz. Heem } \\
\text { Sohna, Sonali, Rupali, NS } 816 \text {, NS } 812 \text {, Pusa Ruby, Indus } 1030 \text {, Arti, DVRT-2, Hybrid } \\
\text { no. } 15 \text { and local showed susceptible reaction. Different insecticide (imidacloprid, }\end{array}$ \\
\hline Article Info & thiamethoxam, dimethoate, acetamiprid, profenofos and oxy-demeton methyl) were \\
\hline $\begin{array}{l}\text { Accepted: } \\
\text { 12 March } 2017 \\
\text { Available Online: } \\
10 \text { April } 2017\end{array}$ & $\begin{array}{l}\text { DAT seed treatment }+ \text { seedling dip }+ \text { foliar application of imidacloprid showed lowest } \\
\text { disease intensity followed by foliar application of imidacloprid, seed treatment with } \\
\text { imidacloprid, foliar application of thiamethoxam, foliar application of dimethoate, foliar } \\
\text { application of acetameprid, foliar application of methyl-o-demeton and foliar application } \\
\text { of profenofos treatments, respectively. }\end{array}$ \\
\hline
\end{tabular}

\section{Introduction}

Tomato (Lycopersicon esculentum Mill.) is a herbaceous fruiting plant belonging to the family Solanaceae. It originated in Latin America and has become one of the most popular and widely cultivated vegetable crops of the world with ability to survive in diverse environmental conditions. It is universally treated as "protective food" and provides almost all types of vitamins and minerals in quite fair amount. In the world, tomato is cultivated over an area of 46.15 lakh hectares with an annual production of 1279.9 lakh tonnes and the productivity of 27.73 tonnes per hectare. In India, it occupies an area of about 5.35 lakh hectares producing over 93.62 lakh tonnes with the productivity of 17.5 tonnes per hectare (Anonymous, 2006), while in Jammu region of Jammu \& Kashmir the area under tomato cultivation is 1,280 hectare with the production of 23,550 metric tonnes and productivity of 18.40 tonnes per hectare (Anonymous, 2011). Although area under tomato cultivation is high, the crop is suffering from large number of disease, among them tomato leaf curl disease caused by tomato leaf curl virus (ToLCV) is a major limiting factor in tomato cultivation. In India the virus caused $100 \%$ infection and yield losses up to $90 \%$ (Muniyappa, 2003; Reddy et al., 2011 and Shankarappa et al., 2008). 
Tomato leaf curl virus disease (ToLCVD) is characterized by yellowing of leaf edges, upward leaf cupping, puckering, twisting of leaves, followed by marked reduction in leaf size. The diseased plants look pale and stunted due to shortening of internodal length with more lateral branches resulting in a bushy appearance (Vasudeva and Sam Raj, 1948). The disease is transmitted by whitefly (Bemisia tabaci) of the Family Aleyrodidae (Cohen and Nitzany, 1966) in a persistent and circulative manner and not mechanically or seed transmissible (Green et al., 1987). Considering the importance of the crop, evaluation of different germplasm and insecticides were done under field conditions for the management of the disease.

\section{Materials and Methods}

\section{Screening of tomato germplasm}

Fifteen germplasm of tomato (Samrudhi F-1, Heem Sohna, Sonali, Rupali, Mahaveer, NS 812, NS 816, Pusa ruby, Avinash-2, Indus 1030, Namdhari 82535, Arti, DVRT-2, Hybrid no 15 and local variety), collected from different sources were screened against tomato leaf curl virus under natural epiphytotic conditions for determining resistance against the disease. No plant protection measures were adopted. Observations on disease incidence were recorded at 15 days interval starting from 40 days after transplanting by using the scale given by Sharma and Sharma (1984) (Table $1)$.

\section{Disease scoring}

Percent disease incidence was recorded and calculated by using the following formula:

Percentage of Disease Incidence $=\frac{\text { Number of plants infected }}{\text { Total number of plants observed }} \times 100$

Chemical control: The field experiment was conducted at research farm, Division of Plant
Pathology, Sher-e-Kashmir Agricultural Sciences and Technology, Jammu in a Randomized Block Design with nine treatments and three replication including untreated control with a susceptible variety (Pusa Ruby), three sprays were done for management of the disease under field conditions. The first spray was given at the appearance of the disease symptoms followed by two sprays at 15 days interval. In case of control only water was sprayed.

Percent disease intensity was calculated by using 0-4 scale (Lapidot and Friedmann, 2002) (Table 2).

\section{Observations}

Percentage of disease intensity of tomato leaf curl virus in treated and untreated plots was calculated by using standard formula (McKinney, 1923).

Percentage of Disease Index $(\mathrm{PDI})=$

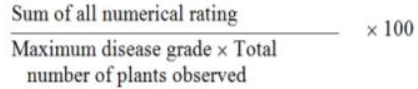

\section{Statistical analysis}

The experiment data was analyzed by using standard methods to test the significance (Gomez and Gomez, 1984).

\section{Results and Discussion}

\section{Screening}

Identification of resistant genotype is one of the important aspects in management of ToLCV disease. In the present study, screening experiment was taken up to access the incidence of the disease in different germplasm (Samrudhi F-1, Heem Sohna, Sonali, Rupali, Mahaveer, NS 812, NS 816, Pusa ruby, Avinash-2, Indus 1030, Namdhari 82535, Arti, DVRT-2, Hybrid no 15 and local variety) under field conditions (Table 3 ). It 
was observed that disease incidence ranged from 0.00 to 66.66 per cent at 70 days after transplanting. Further it was found (Table 4) that out of 15 germplasm, two germplasm viz. Mahaveer, Avinash-2 were found resistant (R), Samrudhi F1 and Namdhari 82535 were found moderately resistant (MR) while Heem Sohna, Sonali, Rupali, NS 812, NS 816, Pusa ruby, Indus 1030, Arti, DVRT2, Hybrid no 15 and local were found susceptible $(\mathrm{S})$.

The screening of different genotypes of tomato for managing the tomato leaf curl disease has been also reported by Hassan et al., (1984); Banerjee and Kalloo (1987); Pilowsky and Cohen (1990); Zakay et al., (1991); Muniyappa et al., (2000); Sajeed Ali et al., (2002); Maruthi et al., (2003); Singh (2014) and Zeshan et al., (2016).

\section{Evaluation of insecticides against tomato leaf curl virus (ToLCV) under field conditions}

Attempts were also made to develop management strategies using different chemicals such as imidacloprid, thiamethoxam, dimethoate, acetamiprid, profenofos and methyl-o-demeton to manage the disease intensity under field conditions. The different insecticides were evaluated to know their efficacy by controlling the vector Bemisia tabaci which is responsible for spread of the disease. From the results, the application of imidacloprid (seed treatment+ seedling dip+ foliar application) at 70 DAT was found most effective treatment in maintaining the disease intensity of $8.14 \%$. The other combinations of imidacloprid were also effective in reducing the disease intensity at different days after transplanting. The other chemical viz. thiamethoxam, dimethoate, acetamiprid, profenofos and oxy-demeton methyl were also found effective in reducing the disease intensity as compared to untreated plots (Table 5).

The minimum disease intensity of $8.14 \%$ was recorded in seed treatment + seedling dip + foliar application of imidacloprid followed by foliar application of imidacloprid (9.62 \%), seed treatment with imidacloprid $(11.10 \%)$, foliar application of thiamethoxam (11.84\%), foliar application of dimethoate (12.59\%), foliar application of acetameprid (13.33 \%), foliar application of methyl-o-demeton (13.33 $\%)$ and foliar application of profenofos (14.07 $\%$ ), whereas per cent disease intensity in control was $(30.73 \%)$.

Yassin et al., (1975), also reported that the application of insecticidal spray delayed the development of leaf curl disease on transplanted tomato and slow down the progress of disease. The application of different insecticides to reduce the incidence of tomato leaf curl disease by checking the whitefly population was also reported by Sastry and Singh (1973); Butter and Rataul (1973); Rajasri et al., (2009); Singh and Prajapati (2014). Manson et al., (2000), conducted an experiment on inhibition of transmissions of ToLCV by using thiamethoxam as soil drench and foliar spray and found that a good level of protection against the disease was given by soil drenching (up to 22 days) than foliar spray. Further, they also reported that the thiamethoxam activity in preventing ToLCV transmission by $B$. tabaci was simply due to killing action and not by anti feedant/repellent action.

Efficacy of imidacloprid to check tomato leaf curl virus under field conditions was also reported by Ahmed et al., (2001), who found that the repeated sprays of imidacloprid reduced disease incidence and the treated plots consistently had higher yields than control plots. 
Table.1 Scale for grading varietal response of tomato germplasm against tomato leaf curl disease

\begin{tabular}{|l|l|l|}
\hline Percent disease incidence & Grade & Reaction group \\
\hline $0-10 \%$ & Resistant & R \\
\hline$>10-30 \%$ & Moderately resistant & MR \\
\hline$>30-70 \%$ & Susceptible & S \\
\hline$>70-100 \%$ & Highly susceptible & HS \\
\hline
\end{tabular}

(Sharma and Sharma, 1984)

Table.2 Disease severity index

\begin{tabular}{|l|l|}
\hline 0 & No visible symptoms. \\
\hline 1 & Slight yellowing of leaflet margins on apical leaf. \\
\hline 2 & Some yellowing and minor curling of leaflet ends. \\
\hline 3 & Curling and cupping, with some reduction in leaf size of plant. \\
\hline 4 & $\begin{array}{l}\text { Severe stunting and yellowing of plant with pronounced leaf cupping } \\
\text { and curling. }\end{array}$ \\
\hline
\end{tabular}

Table.3 Screening of different germplasm of tomato against tomato leaf curl virus under field conditions

\begin{tabular}{|l|l|l|l|l|l|}
\hline \multirow{2}{*}{ S.No } & \multirow{2}{*}{ Germplasm } & \multicolumn{3}{|l|}{ Disease Incidence (\%) } & \multirow{2}{*}{ Grade } \\
\cline { 3 - 6 } & & 40 DAT & 55DAT & 70DAT & \\
\hline 1 & Samrudhi F1 & 22.22 & 25.92 & 29.62 & MR \\
\hline 2 & Heem sohna & 29.62 & 33.33 & 37.03 & S \\
\hline 3 & Sonali & 33.33 & 40.74 & 40.74 & S \\
\hline 4 & NS 812 & 40.74 & 48.14 & 48.14 & S \\
\hline 5 & Pusa ruby & 59.25 & 62.96 & 66.66 & S \\
\hline 6 & Mahaveer & 0 & 0 & 0 & R \\
\hline 7 & Rupali & 48.14 & 51.85 & 55.55 & S \\
\hline 8 & Indus 1030 & 33.33 & 37.03 & 40.74 & S \\
\hline 9 & Namdhari 82535 & 22.22 & 23.33 & 25.92 & MR \\
\hline 10 & DVRT-2 & 37.03 & 44.44 & 44.44 & S \\
\hline 11 & N.S.-816 & 44.44 & 48.14 & 50.00 & S \\
\hline 12 & Avinash-2 & 0 & 0 & 0 & R \\
\hline 13 & Arti & 48.14 & 51.85 & 59.25 & S \\
\hline 14 & Hybrid no 15 & 25.92 & 29.62 & 33.33 & S \\
\hline 15 & Local & 50.00 & 59.25 & 62.96 & S \\
\hline
\end{tabular}


Table.4 Summary of disease reaction of different germplasm against tomato leaf curl virus under field conditions

\begin{tabular}{|l|l|l|l|}
\hline Reaction & $\begin{array}{l}\text { Disease Incidence } \\
(\%)\end{array}$ & No. of entries & Germplasm \\
\hline Resistant & 0 & 2 & Avinash-2, Mahaveer \\
\hline Moderately resistant & $1-30$ & 2 & $\begin{array}{l}\text { Samrudhi F1, Namdhari } \\
82535 \text { S }\end{array}$ \\
\hline Susceptible & $>30-70$ & 11 & $\begin{array}{l}\text { Heem Sohna, Sonali, } \\
\text { Rupali, NS 812, NS 816, } \\
\text { Pusa Ruby, Indus 1030, } \\
\text { Arti, DVRT-2, Hybrid no } \\
15 \text { and local variety }\end{array}$ \\
\hline Highly Susceptible & $>70-100$ & 0 & --- \\
\hline
\end{tabular}

Table.5 Evaluation of different Insecticides against tomato leaf curl virus (ToLCV) under field conditions in variety Pusa Ruby

\begin{tabular}{|c|c|c|c|}
\hline \multirow{2}{*}{ Treatment } & \multicolumn{3}{|c|}{ Percent Disease Intensity } \\
\hline & 40 DAT & 55 DAT & 70 DAT \\
\hline Foliar appilicaton of Profenofos & $\begin{array}{l}7.40 \\
(15.74)\end{array}$ & $\begin{array}{l}11.85 \\
(20.11)\end{array}$ & $\begin{array}{l}14.07 \\
(22.00)\end{array}$ \\
\hline Foliar application of Methyl-o-demeton & $\begin{array}{l}9.62 \\
(18.04)\end{array}$ & $\begin{array}{l}11.10 \\
(19.39)\end{array}$ & $\begin{array}{l}13.33 \\
(21.40)\end{array}$ \\
\hline Foliar application of Dimethoate & $\begin{array}{l}7.40 \\
(15.74)\end{array}$ & $\begin{array}{l}11.10 \\
(19.39)\end{array}$ & $\begin{array}{l}12.59 \\
(20.75)\end{array}$ \\
\hline Foliar application of Thiamethoxam & $\begin{array}{l}6.66 \\
(14.81)\end{array}$ & $\begin{array}{l}7.40 \\
(15.74)\end{array}$ & $\begin{array}{l}11.84 \\
(20.04)\end{array}$ \\
\hline Foliar application of Imidacloprid & $\begin{array}{l}5.92 \\
(14.01)\end{array}$ & $\begin{array}{l}8.14 \\
(16.53)\end{array}$ & $\begin{array}{l}9.62 \\
(17.89)\end{array}$ \\
\hline Foliar application of Acetamiprid & $\begin{array}{l}10.36 \\
(18.75)\end{array}$ & $\begin{array}{l}11.11 \\
(19.46)\end{array}$ & $\begin{array}{l}13.33 \\
(21.40)\end{array}$ \\
\hline Seed treatment with Imidacloprid & $\begin{array}{l}6.66 \\
(14.81)\end{array}$ & $\begin{array}{l}8.33 \\
(17.24)\end{array}$ & $\begin{array}{l}11.10 \\
(19.39)\end{array}$ \\
\hline $\begin{array}{l}\text { Seed treatment+Seedling dip +foliar application with } \\
\text { Imidacloprid }\end{array}$ & $\begin{array}{ll}4.44 \\
(11.89)\end{array}$ & $\begin{array}{l}5.18 \\
(13.08)\end{array}$ & $\begin{array}{l}8.14 \\
(16.53)\end{array}$ \\
\hline 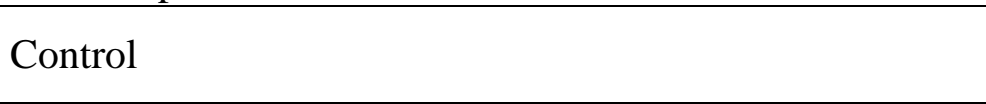 & $\begin{array}{l}24.07 \\
(29.36)\end{array}$ & $\begin{array}{l}27.40 \\
(31.51)\end{array}$ & $\begin{array}{l}30.73 \\
(33.63)\end{array}$ \\
\hline SE (m) & 0.98 & 0.95 & 1.02 \\
\hline $\mathrm{CD}(\mathrm{P}=0.05)$ & 2.99 & 2.88 & 3.08 \\
\hline
\end{tabular}

Gajanana et al., (2006) also reported that root dipping of tomato seedlings in imidacloprid just before transplanting followed by spraying at 15 days after planting gave greater reduction in incidence of tomato leaf curl virus. The overall view of the table suggest that at 40 DAT and 70 DAT there was no significant variation in disease intensity in the 
plots treated with seed treatment + seedling dip + foliar application of imidacloprid, foliar application of imidacloprid and seed treatment of imidacloprid.

\section{Acknowledgement}

The author is highly thankful to the Department of Biotechnology, Govt. of India for financial help in funding the project and Division of Plant Pathology, SKUASTJammu Chatha, Jammu and Kashmir for providing facilities for research work.

\section{References}

Ahmed, N.E., Kanan, H.O., Sugimoto, Y., Ma, Y.Q. and Inanaga, S. 2001. Effect of imidacloprid on incidence of Tomato yellow leaf curl virus. Plant Dis., 85(1): 84-87.

Anonymous. 2006. Indian Horticulture Database, Chapter 02, Tomato, pp 177185.

Anonymous. 2011. Vegetable production in India: Technical Bulletin, IIVR, Varanasi, 51: 250 .

Banerjee, M.K. and Kalloo, G. 1987. Inheritance of tomato leaf curl virus resistance in Lycopersicon hirsutum, $f$. glabratum. Euphytica, 36: 581-584.

Butter, N.S. and Rataul, H.S. 1973. Control of tomato leaf curl virus (TLCV) in tomatoes by controlling the vector whitefly Bemisia tabaci Gen. by mineral oil sprays. Curr. Sci., 42 (24): 864-865.

Cohen, S. and Nitzany, F.E. 1966. Transmission and host range of the tomato yellow leaf curl virus. Phytopathol., 56: 1127-1131.

Gajanana, T.M., Krishna Moorthy, P.N., Anupama, H.L., Raghunatha, R. and Prasanna Kumar, G.T. 2006. Integrated pest and disease management in Tomato: An Economic Analysis. Agricultural Economics Res. Rev., 19: 269- 280.

Gomez, K.A. and Gomez, A.A. 1984. Statistical Procedures for Agri. Res., pp 95-109.

Green, S.K., Sulyo, Y. and Lesemann, D.E.
1987. Outbreaks and new records of leaf curl virus on tomato in Thaiwan province. FAO Plant Protection Bullettin, 35: 62.

Hassan, A.A., Mayzed, H.M., Mustafa, S.E.Nassar, S.H., Nakhle, M.K. and Sims, W.F. 1984. Inheritance of resistance to tomato yellow leaf curl virus derived from Lycopersicon cheesmani and $L$. hirsutum. Horticulture Sci., 19: 574-575.

Lapidot, M. and Friedmann, M. 2002. Breeding for resistance to whitefly-transmitted Gemini viruses. Ann. Appl. Biol., 140: 109-127

Manson, G. Rancati, M. and Basco, D. 2000. The effect of thiomethaxam, a second generation neonicotinoid insecticide in preventing transmission of tomato yellow leaf curl Gemini virus (TYLCV) by the whitefly, Bemisia tabaci (Gennadius). Crop Protection, 19(7): 473-479.

Maruthi, M.N., Czosnek, H., Vidavski, F., Tarba, S.Y., Milo, J., Leviatov, S., Venkatesh, H.M., Padmaja, A.S., Kulkarni, R.S., Venkataramappa, and Muniyappa, V. 2003. Comparison of resistance to tomato leaf curl virus (India) and tomato yellow leaf curl virus (Israel) among Lycopersicon wild species, breeding lines and hybrids. European J. Plant Pathol., 109: 1-11.

McKinney, H.H. 1923. A new system of grading plant diseases. J. Agri. Res., 26: 195-218.

Muniyappa, V. 2003. Comparison of resistance to tomato leaf curl virus (India) and tomato yellow leaf curl virus (Israel) among Lycopersicon wild species, breeding lines and hybrids. European J. Plant Pathol., 109: 1-11.

Muniyappa, V., Venkatesh, H. M., Ramappa, H. K, Kulkarni, R. S., Zeidan, M., Tarba, C.Y., Ghanim, M. and Czosnek H. 2000. Tomato leaf curl virus from Bangalore (ToLCV-Ban4): sequence comparison with Indian ToLCV isolates, detection in plants and insects, and vector relationships. Archives of Virol., 145(8): 1583-98.

Pilowsky, M. and Cohen, S. 1990. Tolerance to 
tomato yellow leaf curl virus derived from Lycopersicon peruvianum. Plant Dis., 74: 248-250.

Rajasri, M., Lakshmi, K.V., Rao, R.D.V.J.P. and Reddy, K.L. 2009. Management of whitefly transmitted Tomato leaf curl virus using guard crops in tomato. Indian J. Plant Protection, 37 (1/2): 101-103.

Reddy, B.A., Patti, M.S., Reddy, K.M. and Venkataravanappa, V. 2011. Detection and diagnosis of Tomato leaf curl virus infecting tomato in Northern Karnataka. African J. Agri. Res., 6(5): 1051-1057.

Sajeed, A., Nath, B.K., Yadav, P.S., Wangchu, V.B., L. and Ali, S. 2002 Tomato leaf curl virus disease on different tomato cultivars in the New Alluvial Zone of West Bengal. Environ. Ecol., 20: 908-911.

Sastry, K.M.S. and Singh, S.J. 1973. Assessment of losses in tomato caused by tomato leaf curl virus. Indian J. Mycol. Plant, Pathol., 3: 50-54.

Shankarappa, K.S., Sriharsha, R.K.T., Aswathanarayana, D.S., Prameela, H.A., Kulkarni, R.S., Muniyappa, V., Mohan, R.A. and Maruthi, M.N. 2008. Development of tomato hybrids resistant to tomato leaf curl disease in South India. Euphytica, 164: 531-539.

Sharma, B.R. and Sharma, O.P. 1984. Field reaction of some root-knot resistant tomato varieties and hybrids to tobacco mosaic and tobacco leaf curl viruses. Indian J. Mycol. Plant Pathol., 14: 148150.

Singh, K. 2014. Evaluation of tomato genotypes and its reaction against ToLCV causing leaf curl disease in tomato (Lycopersicon esculetum L.). J. Experimental Biol. Agri. Sci., 2(15).

Singh, S.R. and Prajapati, R.K. 2014. Assessment of integrated management of leaf curl virus in tomato on farmers' fields at Mahamaya Nagar district of Uttar Pradesh. Agriways, 2(2): 119-125.

Vasudeva, R.S. and Samraj. 1948. Leaf curl disease of tomato. Phytopathol., 18: 364369.

Yassin, A.M. 1975. Epidemics and chemical control of leaf curl disease of tomato in Sudan. Experimental Agri., 11: 161-165.

Zakay, Z., Navot, N., Zeidan, M., Kedar, N., Rabinowitch, H., Czosnek, H. and Zamir, D. 1991. Screening Lycopersicon accessions for resistance to tomato yellow leaf curl virus: Presence of Viral DNA and Symptom Development. Plant Dis., 75: 279-281.

Zeshan, M.A., Khan, M.A., Ali, S. and Arshad, M. 2016. Phenotypic evaluation of tomato germplasm for the source of resistance against tomato leaf curl virus disease. The J. Animal and Plant Sci., 26(1): 194-200.

\section{How to cite this article:}

Dechan Choskit, Ranbir Singh, Sonali Bhagat, Kausar Fatima, Manika Sharma and Sachin Gupta. 2017. Evaluation of Different Germplasm and Insecticides against Tomato Leaf Curl Virus Affecting Tomato. Int.J.Curr.Microbiol.App.Sci. 6(4): 1080-1086. doi: https://doi.org/10.20546/ijcmas.2017.604.134 